\title{
アレルギー性気管支喘息発症における機能分子に関する研究
}

\author{
田中宏幸
}

\section{Functional Molecules in Allergic Bronchial Asthma}

\author{
Hiroyuki TANAKA \\ Department of Pharmacology, Gifu Pharmaceutical University, \\ 5-6-1 Mitahora-Higashi, Gifu 502-8585, Japan
}

(Received May 29, 2002)

\begin{abstract}
Bronchial asthma is considered to be a chronic airway inflammatory disease, characterized by airway obstruction, airway eosinophilic inflammation, and airway hyperresponsiveness (AHR) to a variety of stimuli. AHR is thought to be an important symptom, because the severity of the disease is generally correlated with the degree of AHR. Recent clinical studies have demonstrated the involvement of airway inflammation in the development of allergen-induced AHR, although, the mechanism of allergen-induced AHR has not been fully elucidated and remains controversial. In vivo animal models might provide important information on this point. We have established a mouse model of allergic asthma, which is characterized by airway eosinophilia, IgE production, T helper type 2 (Th2) cytokine production in the airway, and AHR, and investigated the role of inflammatory cells and functional molecules. Results from gene-knockout and mutant mice demonstrated the involvement of T cells, mast cells, prostanoids, and Th2 cytokines including interleukin (IL) -4 and IL -5 in the development of allergen-induced airway inflammation and AHR. In contrast, treatment with anti-IL-4 monoclonal antibody (mAb) or anti-IL-5 mAb during allergen inhalation did not inhibit allergen-induced AHR, although the combination of these mAbs clearly inhibited the enhanced responsiveness. These data indicate that it is a better strategy for control of the disease to inhibit or suppress multifunctional molecules like corticosteroids rather than to inhibit a single factor, because bronchial asthma is a multifactorial disease.
\end{abstract}

Key words_— bronchial asthma; T cells; mast cells; Th2; prostaglandin; cytokines

\section{1. はじめに}

気管支喘息は，気道閉塞，気道内好酸球増多並び に気道反応性六進，すなわち気道過敏性を特徴とす る閉塞性呼吸器疾患である。このうち, 特に気道過 敏性は, 種々の物理的・化学的刺激に対し気道が健 常人に比し収縮しやすくなっている状態を指し, 呼 気性呼吸困難症状の主たる発現要因となっている. 気管支喘息は，血清中抗原特異的 IgE 值が高值で かつ抗原特異的な喘息症状の発現が認められるアト ピー型気管支喘息と特異抗原が検出できない非ア卜 ピー型気管支喘息の 2 つに大きく分けられる．アト ピー型気管支喘息に関しては，特異抗原による種々 の反応の解析及び動物モデルを用いた病態の外挿に

岐阜薬科大学薬理学教室（厂502-8585 岐阜市三田洞東 5-6-1)

e-mail: hirotnk@gifu-ppu.ac.jp

*本総説は, 平成 13 年度日本薬学会東海支部学術奨励 賞の受賞を記念して記述したものである.
より，これまでにその発症機序に関して多くの研究 がなされてきたが，特に気道過敏性発症機序に関し ては不明な点が多い.

著者らは，遺伝子背景が明らかなマウスを用い て, 抗原誘発気道炎症及び気道過敏性モデルを作成 し, その発症に関与する細胞及び機能分子に関して 検討を行ってきた。ここでは, これまでに教室で得 られた成績を中心に, 気道過敏性発症機序に関与す る細胞及び機能分子に関して論述する. なお, 教室 で得られているこれまでの成績は, 紙面の都合上,

Table 1 にまとめたので参考にしていただきたい.

\section{2. 喘息モデルの確立とその特徵}

従来, 動物モデルとしては種々の刺激による気道 の反応性の類似性からモルモットが頻用されてきた が, 遺伝子背景が不明確であり, また, 抗体などの 解析用試薬も不十分であることから, 患者の症状と の類似性は認められても, より詳細な検討は困難で あった。そこで教室では, 遺伝子背景が明確かつ種 
Table 1. Role of Inflammatory Cells and Functional Molecules in the Development of Antigen-Induced Airway Inflammation and Hyperresponsiveness in Mice

\begin{tabular}{|c|c|c|c|c|c|c|}
\hline & & $\operatorname{IgE}$ & Eosinophilia & IL-5 & $\mathrm{AR}$ & Ref. \\
\hline \multirow[t]{6}{*}{$\mathrm{BALB} / \mathrm{c}$} & & $\uparrow \uparrow$ & $\uparrow \uparrow$ & $\uparrow \uparrow$ & $\uparrow \uparrow$ & \\
\hline & athymic mice & & - & - & \pm & 4 \\
\hline & c-kit mutant $\mathrm{W} / \mathrm{W}^{\mathrm{V}}$ & & $\uparrow \uparrow$ & $\uparrow \uparrow$ & \pm & 6 \\
\hline & DPKO & $\uparrow \uparrow$ & $\uparrow /-$ & $\uparrow /-$ & \pm & 7 \\
\hline & IL-4 KO & - & $\uparrow /-$ & $\uparrow /-$ & \pm & 10 \\
\hline & IL-5R $\alpha$ chain $\mathrm{KO}$ & $\uparrow \uparrow$ & $\uparrow /-$ & $\uparrow \uparrow$ & \pm & 13 \\
\hline \multirow[t]{8}{*}{$\mathrm{BALB} / \mathrm{c}$} & during Ag inhalation & & & & & \\
\hline & Cyclosporin A & & $\uparrow /-$ & $\uparrow /-$ & \pm & 4 \\
\hline & FK-506 & & $\uparrow /-$ & $\uparrow /-$ & \pm & 4 \\
\hline & anti-allergic drugs & & $\uparrow \uparrow$ & $\uparrow \uparrow$ & $\uparrow \uparrow$ & 6 \\
\hline & anti-IL-4 mAb & $\uparrow /-$ & $\uparrow \uparrow$ & $\uparrow \uparrow$ & $\uparrow \uparrow$ & 11,16 \\
\hline & anti-IL-5 mAb & $\uparrow \uparrow$ & $\uparrow /-$ & & $\uparrow \uparrow$ & 6,16 \\
\hline & Soluble IL-5R & & $\uparrow /-$ & & $\uparrow \uparrow$ & 1 \\
\hline & Combination & $\uparrow /-$ & $\uparrow /-$ & & \pm & 16 \\
\hline
\end{tabular}

$\mathrm{Ag}$ : antigen, AR: airway responsiveness to acetylcholine, DP: prostaglandin D receptor, KO: gene knockout, mAb: monoclonal antibody, R: receptor. $\uparrow \uparrow:$ marked increase, $\uparrow:$ moderate increase, \pm : not observed, - : not observed or detected. blank: not determined.

Airway responsiveness
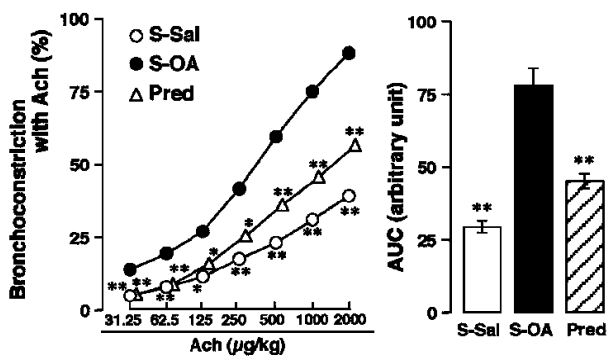

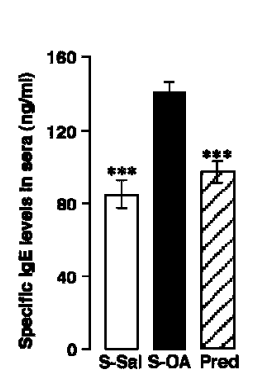

Immune responses

Inflammatory infiltrates in BALF (right lungs)
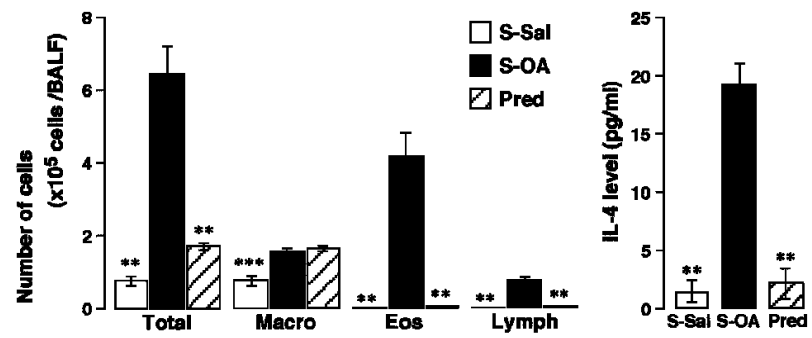

Cytokine levels in BALF (right lungs)

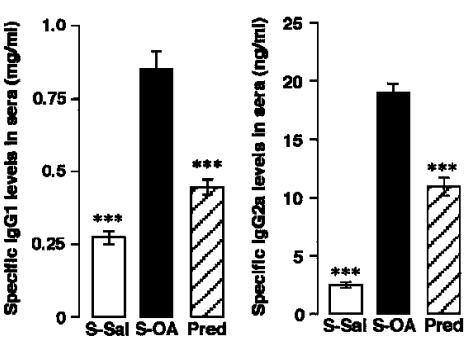

Fig. 1. Representative Data of Allergen-Induced Airway Inflammation and Hyperresponsiveness to Acetylcholine (Ach) in a Mouse Model of Allergic Asthma

AUC: area under the curve (range 31.25-2000 $\mathrm{g} / \mathrm{kg}$ ), BALF: bronchoalveolar lavage fluid, Eos: eosinophils, IFN: interferon, Lymph: lymphocytes, Macro: macrophages, OA: ovalbumin-inhaled, Pred: prednisolone (p.o. during antigen inhalation for 10 days), S: sensitized, Sal: Saline-inhaled. ${ }^{*} \mathrm{p}<0.05$, ${ }^{* *} \mathrm{p}<0.01$, $* * * \mathrm{p}<0.001$ (vs S-OA).

々の試薬類も充実しているマウスを用いて喘息モデ ルの確立を行った.

すなわち, 高 $\operatorname{IgE}$ 産生系マウスとして知られて いる BALB/c マウスを抗原として卵白アルブミン 及びアジュバント（水酸化アルミニウム）により能
動的に感作し, その後, 抗原（1\%生理食塩水溶液） を 3 回吸入させた. その結果, Fig. 1 に示すように 最終抗原吸入 24 時間後では, 気管支肺胞洗浄液 (BALF) 中に好酸球を主体とする炎症性細胞の増 加, ヘルパー 2 型サイトカイン（Th2）である IL- 
4, IL-5 及び IL-13 量の増加, 血清中抗原特異的 $\mathrm{IgE}$ 及び IgG1 值の上昇並びにアセチルコリンによ る気道収縮反応の充進，すなわち気道過敏性が認め

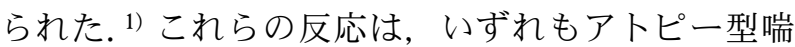
息患者において認められることから，本モデルは抗 原暴露による好酸球性気道炎症及び気道過敏性の発 症機序を解明する上で非常に有用なモデルであると 思われる。

また， 1 ないし 3 回抗原吸入をした際の経時的な 変化を検討したところ, BALF 中の好酸球の分化 · 増殖などに必須の Th2 サイトカインである IL-5 並 びに好酸球数は，2 回目の抗原暴露後から検出され， 3 回目の抗原暴露によりさらに上昇あるいは増加が 認められた。また，気道過敏性に関しても 3 回目の 抗原暴露後に初めて観察されたことから, 気道過敏 性発症にはこのような抗原の反復暴露が必要である ことが明らかとなった. ${ }^{11}$

\section{3. $\mathrm{T}$ 細胞の関与}

$\mathrm{T}$ 細胞は免疫反応において中心的な細胞であり, 外来抗原の侵入後, 樹状細胞などによる抗原提示を 受け，抗原特異的 $\mathrm{CD} 4^{+} \mathrm{T}$ 細胞が増殖・活性化され る.この際, 産生するサイトカイン産生パターンに より，ヘルパー 1 型 $\mathrm{T} （ \mathrm{Th} 1 ）$ 細胞と Th2 細胞に分 類されることが知られている. ${ }^{2)}$ この分類が示され て以来，アレルギー性疾患の多くは Th2 依存性の 反応であることが明らかにされている，実際に，ア トピー型気管支喘息の気道粘膜生検及び BALF 中 には Th2 サイトカインに属する IL-4, IL-5 及び IL -13 が検出されている. ${ }^{3)} し$ か, 抗原誘発気道過 敏性の発症において $\mathrm{T}$ 細胞の役割は不明であつ た。そこで教室では, 本反応の $\mathrm{T}$ 細胞依存性を確 認する目的で, 先天的胸腺欠損マウス及び種々の免 疫抑制薬を抗原暴露時に投与しその影響を検討し た。その結果，先天的胸腺欠損マウスでは，上述の 反応はいずれも観察されず，免疫抑制薬のうち，特 にサイクロスポリン A 及び FK-506 が BALF 中好 酸球増多, IL-5 産生並びに気道過敏性を用量依存 的に有意に抑制した. ${ }^{4}$

以上の成績より, 本モデルにおける気道内好酸球 増多及び気道過敏性発症には, $\mathrm{T}$ 細胞が必須の細胞 であることが明らかとなった。

\section{4. 肥満細胞の役割}

肥満細胞は, その細胞膜表面上に $\operatorname{IgE}$ 抗体の $\mathrm{Fc}$
部分に対し高親和性の F $c \varepsilon R I$ 受容体を発現してお り, 抗原特異的 $\operatorname{IgE}$ 抗体の固着により感作状態が 成立する。周知のように, 抗原の再侵入及び $\operatorname{IgE}$ 抗体の $\mathrm{Fab}$ 部分における架橋により, 肥満細胞内 に刺激が加わり, 細胞内顆粒の放出並びにアラキド ン酸代謝産物の産生及びサイトカインの合成・産生 が生ずる. ${ }^{5)}$ 気管支喘息における肥満細胞の役割 は，前述のように抗原抗体反応による脱顆粒により 放出されたヒスタミンあるいはアラキドン酸代謝産 物の産生により，直接，気道平滑筋の収縮に関与す ることが知られている. しかし, 抗原暴露後に生じ る気道内好酸球増多並びに気道過敏性発症における その役割は不明であった。 そこで, 肥満細胞の増殖 因子である c-kit 遺伝子の突然変異マウスである $\mathrm{WBB} \mathrm{F}_{1}-\mathrm{W} / \mathrm{W}^{\mathrm{v}}$ マウスを用いてその意義を解析し た。 その結果, 対照マウスに比し肥満細胞欠損マウ スでは，BALF 中 IL-5 産生及び好酸球増多に関し ては差が認められなかったが, 気道過敏性について は発症が認められなかった. ${ }^{6}$ 一方，これまでに臨 床で用いられている肥満細胞からのメディエーター 遊離抑制薬は，いずれの反応に対してもほとんど影 響を及ぼさなかった。 ${ }^{6)}$ 以上の成績は，肥満細胞は 気道過敏性発症に重要な細胞であることを示唆する ものであるが，その一方で，これまでに開発された メディエーター遊離抑制薬では気道過敏性の制御は 困難であることが推察された.

そこで, さらに肥満細胞の気道過敏性発症におけ る役割を検討する目的で, 肥満細胞から産生される プロスタノイドのうち, 特にプロスタグランジン D2（PGD2）に着目し，その受容体である DP 遺伝 子欠損マウスを用いて検討を行った. PGD2 は, 臨 床においても抗原暴露後の肥満細胞活性化の指標に も用いられ，BALF 中にも大量に産生されることが 知られているプロスタノイドである，従来，気道収 縮物質として知られていたが，その選択的拮抗薬も 開発されていなかったことから，気道炎症並びに気 道過敏性における意義については不明であった。結 果として, DP 遺伝子欠損マウスでは, 野生型マウ スで観察された気道炎症, Th2 サイトカイン産生及 び気道過敏性のいずれも減弱が認められた. 7)した がって, PGD2 は気道収縮物質としてだけではな く, 恐らく Th2 サイトカイン産生を介しアレル ギー性気道炎症の増幅にも関与しているものと思わ 
れる。

また，PGD2の受容体に関しては，近年，ヒトの リンパ系細胞において CRTH2 という受容体がク ローニングされ，PGD2 とほぼ同程度の親和性を有 することが示されている. ${ }^{8)}$ マウウスに関する情報は まだ明らかにされていないが，PGD2 が DP 受容体 とは全く異なるケモカイン受容体である CRTH2 に も結合し細胞遊走に関与する可能性があることは, 非常に興味が持たれるところであり今後の研究成果 が期待される.

\section{IL-4 の役割}

IL-4 は，上述のように Th2 サイトカインの 1 つ であり，ナイーブ $\mathrm{CD} 4{ }^{+} \mathrm{T}$ 細胞（一度も外来抗原を 認識していない $\mathrm{CD}^{+} \mathrm{T}$ 細胞) から $\mathrm{Th} 2$ 細胞への 分化誘導, B 細胞からの IgE 産生などに関与するこ とが主として in vitro の実験により報告されてい る9)が, in vivo でのアレルギー性炎症並びに気道過 敏性発症における役割は十分に解析されていなかっ た。そこで，教室では 2 種類の IL-4 遺伝子欠損マ ウス，すなわち $\mathrm{BALB} / \mathrm{c}$ 及び $\mathrm{C} 57 \mathrm{BL} / 6$ 由来のマウ スを用いてその意義を検討した，C57BL/6 マウス の場合, $\operatorname{IgE}$ 産生は 1 次免疫後一過性に上昇が認め られるが, その後減少し, 最終抗原暴露直前ではほ とんど検出されないという特徵を有する。 その結 果, いずれの欠損マウスにおいても, IgE 産生, 気 道内好酸球増多, BALF 中 IL-5 産生並びに気道過

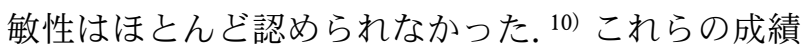
は, IL-4 は初回免疫後の Th2 細胞の分化及びそれ に引き続いて誘導されるアレルギー性炎症に必須で あることを示すのと同時に, 血清中の抗原特異的 IgE 值に関しては, 両マウスの比較検討から気道過 敏性発症と必ずしも連関していないことを示唆して いる，そこで，さらに IL-4 並びに $\operatorname{IgE}$ の意義を検 討する目的で, 抗 IL-4 抗体を抗原暴露期間中に投 与し, 後天的に IL-4の作用を中和した際の影響を 検討した. その結果, IgE 産生は抗 IL-4 抗体投与 により明らかに抑制されたが, 気道内好酸球増多並 びに気道過敏性にはほとんど影響を及ぼさなかっ た. ${ }^{11)}$ 以上のことから，IL-4 は in vivoにおいても $\mathrm{IgE}$ 産生, 気道内好酸球増多並びに気道過敏性発症 に重要な機能分子であるが, 上述の成績は IL-4 の 作用を ongoing な状態で抑制しても気道過敏性の 制御は困難であることを示している.

\section{IL-5 の意義}

IL-5 も IL-4 と同様, Th2 サイトカインの 1 つで あるが, IL-5 は特に好酸球の分化・増殖・活性化 に必須の機能分子12)であり, 好酸球性炎症の発症に おいて重要な役割を有することが知られている。し かし, 抗原暴露による気道過敏性発症における役割 は不明であった。そこで教室では，抗 IL-5 抗体, 可溶化 IL-5 受容体並びに IL-5 受容体 $\alpha$ 鎖欠損マ ウスを用いてその意義を検討した。 IL-5 受容体 は，周知のように $\alpha$ 鎖と $\beta$ 共通鎖からなる。この うち $\alpha$ 鎖は IL-5 の刺激を特異的に伝達する受容体 であるが， $\beta$ 共通鎖は IL-3 や granulocyte-macrophage colony stimulating factor (GM-CSF) と共通 の受容体である。まず，この $\alpha$ 鎖欠損マウスでは, IgE 産生並びに IL-5 産生は野生型マウスと差は認 められなかったが, 気道内好酸球はほとんど認めら

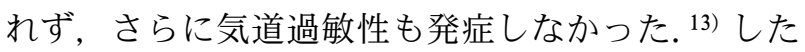
がって, IL-5 は本モデルにおける気道内好酸球増 多はもとより, 気道過敏性発症においても重要な役 割を有することが示唆された。一方，上述の IL-4 での検討同様, 抗原暴露時に IL-5 の作用を中和抗 体6) あるいは可溶化受容体1)を投与し検討したとこ ろ, 気道内好酸球増多は明らかに抑制されたが, 気 道過敏性にはほとんど影響を及ぼさなかった。 以上 の成績は, IL-4 の場合と同様に, IL-5 の場合もそ の作用を ongoing な状態で抑制しても気道過敏性 の制御は困難であることを示している.

この点に関しては，近年，欧米において抗 IL-5 抗体の臨床知見が行われた結果，ほぼ同様の成績が 報告されている. ${ }^{14)}$ すなわち，抗 IL-5 抗体を喘息 患者に投与した際, 喀痰中の好酸球数並びに血中の 好酸球数ともに有意な抑制が認められたが，気道過 敏性に関してはほとんど効果が認められないことが 示された。 さらに，近年，同様のマウスモデルを用 いた検討から, 抗原暴露による気道過敏性が発現し た時点から抗 IL-5 抗体を投与した場合, その効果 がほとんど認められないことも報告されている. ${ }^{15)}$ 現在, この治験成績に関しては, 症例数や測定項目 などで現在もなお論議がなされているところではあ るが，その一方で，本論文は臨床においても吸入ス テロイドなどのような複合的な作用を有する治療法 に比し, 単一の機能分子の抑制という治療法の限界 を示しているのかも知れない. 


\section{7. 抗原暴露時における IL-4 並びに IL-5 の作用} の中和

上述のように IL-4 あるいは IL-5 の作用を抗原 暴露時に中和しても症状の改善は認められなかった ことから, 両者の中和を目的とし, それぞれの中和 抗体を同時に投与しその影響を単独処置の場合と比 較検討した。 その結果, 両者を同時に中和した際に は, 血清中抗原特異的 $\operatorname{IgE}$ 值の上昇, 気道内好酸 球増多並びに気道過敏性のいずれも有意に抑制され

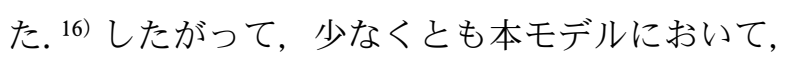
アレルギー性気道炎症獲得後の症状の是正には, IL-4 及び IL-5 の両者の作用の抑制が重要であるこ とが示唆された。

\section{8. おわりに}

以上，これまでに教室で得られた成績を中心にア レルギー性気管支喘息の好酸球増多並びに気道過敏 性発症に関与する細胞並びに機能分子に関して概説 した. Figure 2 は, 教室で得られた成績及びこれま での報告から, アレルギー性気道炎症及び気道過敏 性発症に関与する細胞並びに機能分子をまとめたも のである. 上述のように, 最近, アトピー型気管支
喘息の基礎研究は, 特に遺伝子背景が明確であり, 種々の遺伝子改変動物が作成されたことからマウス を用いた検討が主流となりつつあるが，これらのモ デルにおいても問題点が指摘されている.すなわ ち, 同一系統のマウス, すなわち遺伝子背景が同一 のマウスを用いても, 感作条件あるいは抗原暴露の 条件が異なると, 病態形成に関わる細胞や機能分子 の度合いが異なる可能性が報告されている. ${ }^{17,18)} こ$ のことはヒトに外挿すれば，一卵性双生児において も環境によりターゲット細胞あるいは機能分子が異 なる可能性を示唆しており, ここにも複雑な免疫反 応をべースとするアレルギー疾患の多因子疾患とし ての病態解明及び標的機能分子の探索の難しさが示 されている. また, 遺伝子改変動物を用いた検討の 場合にも, (1)使用したマウスの遺伝子背景, (2)戻し 交配の必要性並びに(3)後天的制御の場合との比較, など最終的な結論を導き出すには問題点も多い.

しかしながら, 近年, 世界的に進められているマ イクロアレイなどの網羅的遺伝子解析により, 今 後, マウス及びヒトにおいて, 未知のあるいはこれ までにアレルギーとの関連性が報告されていないよ

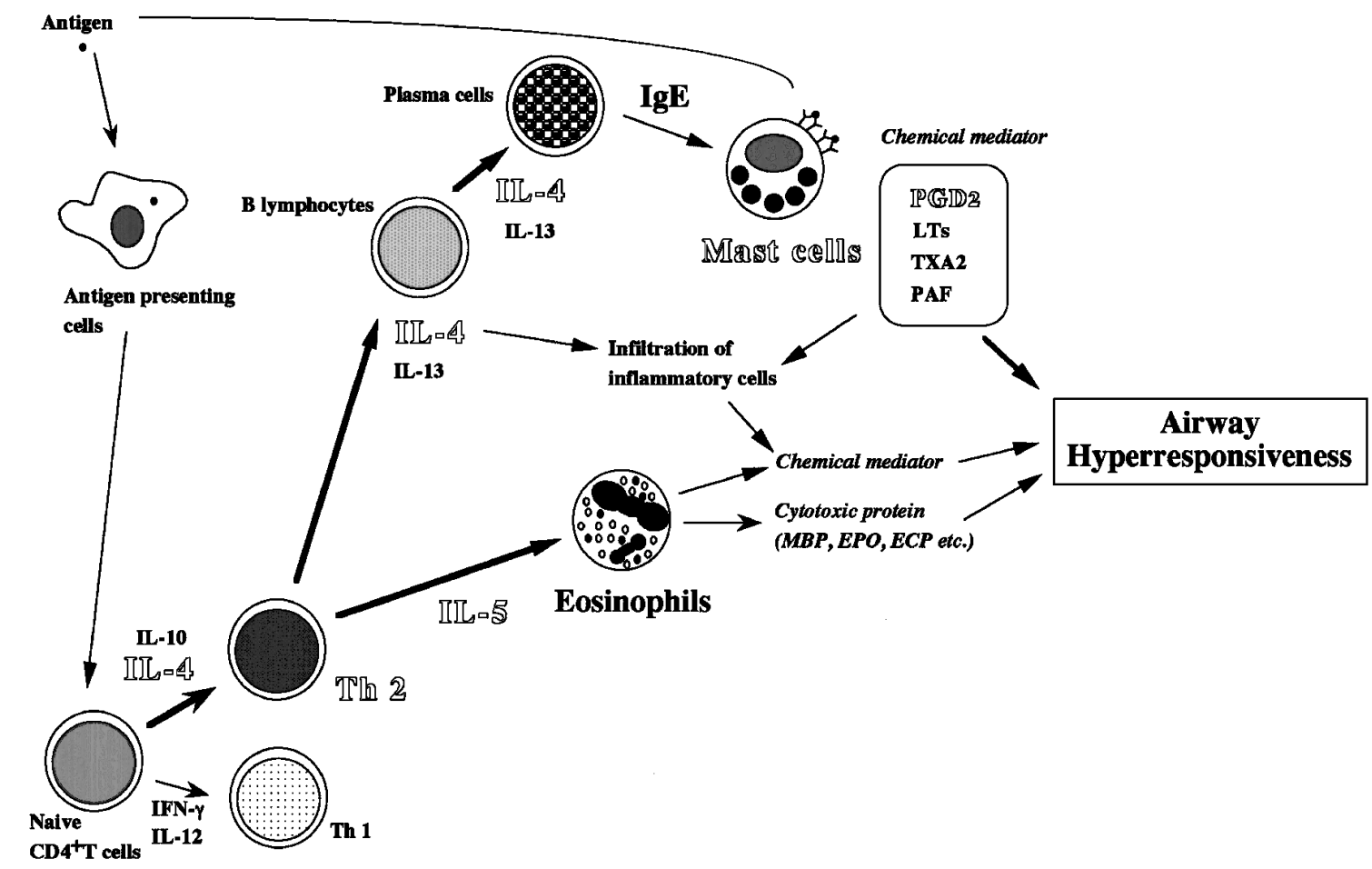

Fig. 2. A Proposal Schema for the Development of Allergen-Induced Airway Inflammation and Hyperresponsiveness in Allergic Bronchial Asthma

ECP: eosinophil cationic protein, EPO: eosinophil peroxidase, IFN: interferon, LTs: leukotrienes, MBP: major basic protein, PAF: platelet activating factor, PGD2: prostaglandin D2, Th: T helper, TXA2: thromboxane A2. 
うな遺伝子が発見される場合が多くなることが予想 される，その際には，遺伝子改変動物あるいはウィ ルス等による気道における遺伝子の強制発現系を用 いたマウス喘息モデルにおける解析が重要な手法に なるものと思われ，今後の研究成果が期待される.

謝辞本総説で紹介した研究成果は, 岐阜薬科 大学薬理学教室で行われたものであり, 終始ご指 導・ご鞭撻を賜りました永井博式教授に深甚なる謝 意を表します。また，研究を遂行するに当たり， IL-5 遺伝子改変動物を譲渡いただきました東京大 学医科学研究所の高津聖志教授に深謝いたします。

さらに, DP 遺伝子久損マウスの成績は, 京都大学 大学院医学研究科の成宮 周教授との共同研究の成 果であり，ここに深謝申し上げます。 また，本研究 において終始ご指導・ご協力いただきました教室の 皆様に心より御礼申し上げます。

\section{REFERENCES}

1) Yamaguchi S., Nagai H., Tanaka H., Tsujimoto M., Tsuruoka N., Life Sci., 54, PL471-475 (1994).

2) Abbas A. K., Murphy K. M., Sher A., Nature, 383, 787-793 (1996).

3) Robinson D. S., Br. Med. Bull., 56, 956-968 (2000).

4) Nagai H., Yamaguchi S., Tanaka H., Inagaki N., Int. Arch. Allergy Immunol., 108, 189195 (1995).

5) Galli S. J., New Engl. J. Med., 328, 257-265 (1993).

6) Nagai H., Yamaguchi S., Maeda Y., Tanaka H., Clin. Exp. Allergy, 26, 642-647 (1996) .

7) Matsuoka T., Hirata M., Tanaka H., Takahashi Y., Murata T., Kabashima K., Sugimoto
Y., Kobayashi T., Ushikubi F., Aze Y., Eguchi N., Urade Y., Yoshida N., Kimura K., Mizoguchi A., Honda Y., Nagai H., Narumiya S., Science, 287, 2013-2017 (2000) .

8) Hirai K., Tanaka K., Yoshie O., Ogawa K., Kenmotsu K., Takamori Y., Ichimasa M., Sugamura K., Nakamura M., Takano S., Nagata K., J. Exp. Med., 193, 255-261 (2001)

9) Brown M. A., Hural J., Crit. Rev. Immunol., 17, 1-32 (1997).

10) Tanaka H., Kawada N., Yamada T., Kawada K., Nagai H., Allergol. Int., 49, 253-261 (2000).

11) Nagai H., Maeda Y., Tanaka H., Clin. Exp. Allergy, 27, 218-224 (1997).

12) Greenfeder S., Umland S. P., Cuss F. M., Chapman R. W., Egan R. W., Respir. Med., 2, 71-79 (2001).

13) Tanaka H., Kawada N., Yamada T., Kawada K., Takatsu K., Nagai H., Clin. Exp. Allergy, 30, 874-881 (2000).

14) Leckie M. J., ten Brinke A., Khan J., Diamant Z., O'Connor B. J., Walls C. M., Mathur A. K., Cowley H. C., Chung K. F., Djukanovic R., Hansel T. T., Holgate S. T., Sterk P. J., Barnes P. J., Lancet, 356, 2144-2148 (2000).

15) Mathur M., Herrmann K., Li X., Qin Y., Weinstock J., Elliott D., Monahan J., Padrid P., Am. J. Respir. Crit. Care Med., 159, 580587 (1999).

16) Tanaka H., Nagai H., Maeda Y., Life Sci., 62, PL169-174 (1998).

17) Kobayashi T., Miura T., Haba T., Sato M., Serizawa I., Nagai H., Ishizaka K., J. Immunol., 164, 3855-3861 (2000).

18）Williams C. M., Galli S. J., J. Exp. Med., 192, 455-462 (2000). 